DOI 10.37882/2223-2974.2021.03.31

\title{
ИНСТРУМЕНТЫ РАЗВИТИЯ МЕЖРЕГИОНАЛЬНОЙ ТОРГОВЛИ МУРМАНСКОЙ ОБЛАСТИ КАК ФАКТОРА РОСТА ВАЛОВОГО РЕГИОНАЛЬНОГО ПРОДУКТА
}

\section{DEVELOPMENT TOOLS \\ OF INTERREGIONAL TRADE \\ OF THE MURMANSK REGION \\ AS A FACTOR OF GROWTH OF GROSS REGIONAL PRODUCTC}

\section{E. Chepurina \\ N. Shchebarova}

Summary: The article examines the economic mechanism of interregional trade and tools for its implementation in the Murmansk region, identifies the main forms of interregional trade at the present stage.

Keywords: trade, interregional cooperation, forms of interregional trade, commodity exchange, instruments of interregional trade.

\author{
Чепурина Елена Олеговна \\ аспирант, Мурманский арктический государственный \\ университет, г. Мурманск \\ sekretarsha71@rambler.ru \\ щебарова Наталья Николаевна \\ Д.э.н., професссор, Мурманский арктический \\ государственный университет, г. Мурманск \\ censey@mail.ru
}

Аннотация: В статье рассмотрен экономический механизм межрегиональной торговли и инструментов ее реализации в Мурманской области, определены основные формы межрегиональной торговли на современном этапе.

Ключевые слова: торговля, межрегиональное сотрудничество, формы межрегиональной торговли, товарообмен, инструменты межрегиональной торговли.

цессы сохранены в штатном режиме

Безусловно, у Мурманской области есть ряд сильных позиций в некоторых отраслях промышленности, таких, как, например, рыбоперерабатывающая, продукты которой активно вывозятся на территорию остальной части России. Но в целом регион ориентирован больше на импорт и мало чем может обеспечить себя сам, если мы говорим об исходном сырье. В структуре ВРП (валовой региональный продукт) преобладают добыча полезных ископаемых и обрабатывающие производства.

Развитие межрегиональных торгово-экономических связей рассматривается нами как приоритетное направление региональной экономической политики. В условиях усиления межрегиональной конкуренции, а также высокого динамизма изменений, происходящих как во внешней среде, так и внутри региона, регулирование межрегионального взаимодействия, поиск путей его развития выступает одним из оснований роста экономики.

В целом международную торговлю в регионе можно рассматривать на следующих уровнях.

1. Двустороннее сотрудничество с административно-территориальными единицами государств Северной Европы:

2. Королевство Норвегия

3. Республика Финляндия

4. Королевство Швеция 


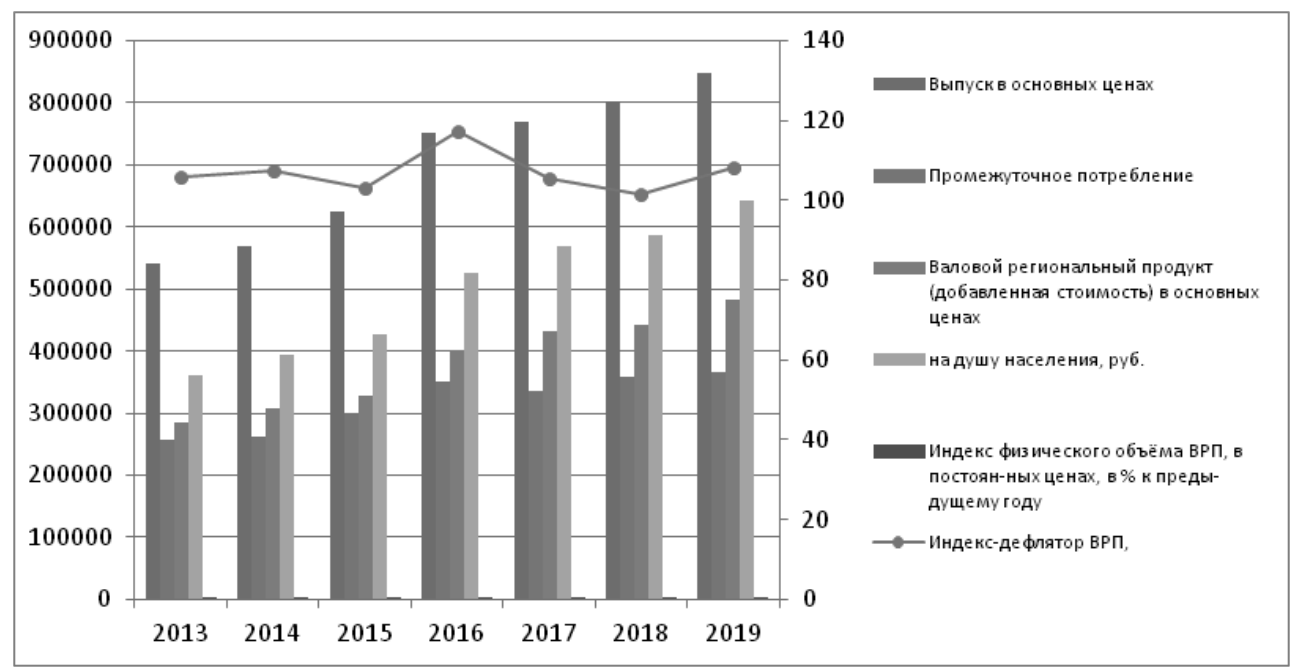

Рис. 1. Производство валового регионального продукта в текущих ценах, миллионов рублей

Таблица 1

Товарная структура экспорта Мурманской области (тыс. долл. США) [2]

\begin{tabular}{|c|c|c|c|c|c|c|}
\hline $\begin{array}{c}\text { Код } \\
\text { ТНВЭД ТС }\end{array}$ & $\begin{array}{c}\text { Наименование } \\
\text { товара }\end{array}$ & 2018г. & $\begin{array}{c}\text { Доля в экспорте } \\
2018 \text { г. }\end{array}$ & 2019г. & $\begin{array}{c}\text { Доля в экспорте } \\
\text { 2019г. }\end{array}$ & $\begin{array}{c}2019 \text { г. } \\
\text { к } 2018 \text { г. }\end{array}$ \\
\hline $01-24$ & $\begin{array}{c}\text { Продовольствен- } \\
\text { ные товары и } \\
\text { сырье для их про- } \\
\text { изводства }\end{array}$ & 252120,3 & $11,3 \%$ & 377226,4 & $17,2 \%$ & $150 \%$ \\
\hline $25-27$ & $\begin{array}{c}\text { Минеральные про- } \\
\text { дукты }\end{array}$ & 776943,3 & $34,9 \%$ & 729929,3 & $33,2 \%$ & $94 \%$ \\
\hline $28-40$ & $\begin{array}{c}\text { Продукция химиче- } \\
\text { ской промышлен- } \\
\text { ности }\end{array}$ & 351,3 & $0,0 \%$ & 488,7 & $0,0 \%$ & $139 \%$ \\
\hline $41-43$ & $\begin{array}{c}\text { Кожевенное сырьё, } \\
\text { меха, } \\
\text { изделия из них }\end{array}$ & 4,5 & $0,0 \%$ & 2,6 & $0,0 \%$ & $58 \%$ \\
\hline $44-49$ & $\begin{array}{c}\text { Древесина, бумага } \\
\text { и изделия из них }\end{array}$ & 1847,8 & $0,1 \%$ & 2225,5 & $0,1 \%$ & $120 \%$ \\
\hline $50-67$ & $\begin{array}{l}\text { Текстиль, текстиль- } \\
\text { ные изделия, обувь }\end{array}$ & 26,6 & $0,0 \%$ & 597,8 & $0,0 \%$ & $2247 \%$ \\
\hline $72-83$ & $\begin{array}{c}\text { Металлы и изделия } \\
\text { из них }\end{array}$ & 1084006,6 & $48,8 \%$ & 952334,0 & $43,3 \%$ & $88 \%$ \\
\hline $84-90$ & $\begin{array}{c}\text { Машины, оборудо- } \\
\text { вание, транспортн. } \\
\text { средства }\end{array}$ & 23599,8 & $1,1 \%$ & 11452,3 & $0,5 \%$ & $49 \%$ \\
\hline & Прочие товары & 84230,6 & $3,8 \%$ & 125297,4 & $5,7 \%$ & $149 \%$ \\
\hline & Итого & 2223130,8 & $100,0 \%$ & 2199553,7 & $100,0 \%$ & $99 \%$ \\
\hline
\end{tabular}

Пути совершенствования межрегиональной торговли Мурманской области:

- создание благоприятных условий для привлечения инвестиций в экономику региона;

- повышение предпринимательской активности и развитие малого и среднего бизнеса;
- формирование условий для инновационной деятельности организаций;

- создание условий для формирования имиджа Мурманской области как региона, открытого для бизнеса и привлекательного для инвестиций, промышленного, транспортного, научного и тури- 
стического центра на Северо-западе России;

- создание условий для использования потенциала внешнеэкономических и межрегиональных связей, приграничного сотрудничества, туризма и торговли в интересах социально-экономического развития региона;

- совершенствование форм и методов регулирования социально-экономических процессов в регионе.

Мурманские власти прогнозируют возобновление роста экономики со следующего года. В 2021 году ВРП составит 102,2\%, в 2022 году - 101,9\%, в 2023 году $102,1 \%$.

Также отмечается, что сохранится в «зелёной зоне» средняя заработная плата по региону (66,5 тыс. рублей в 2020 году - 104,4\% к 2019 году, 101\% - в реальном исчислении), что обусловлено структурой рынка труда региона и «широким спектром антикризисных мер поддержки». В Министерстве экономического развития Мурманской области сообщили, что в регионе $43 \%$ работников трудятся в крупных организациях, $41 \%$ - работники бюджетных организаций, а в сфере малого и среднего предпринимательства занято $16 \%$ работников.

Роста деловой активности в Мурманской области ожидают и в связи с принятием «арктического пакета преференций», а также в связи с созданием ТОР «Столица Арктики». Среднегодовой темп роста инвестиций в 2021-2023 годах ожидают на уровне 103,5\%.

\section{ЛИТЕРАТУРА}

1. Хаджаев, Р.Ш. Межрегиональная торговля как важный фактор обеспечения конкурентоспособности региона / Р.Ш. Хаджаев // Вестник Калининградского филиала Санкт-Петербургского университета МВД России. - 2017 - № 1 (31). - С. 122-125.

2. Стратегия социально-экономического развития мурманской области на период до 2025 года. - [Электронный ресурс]. - Режим доступа. https://economy.gov.ru/material/file/88a7f71f73949514cb639bf1d4779509/030119mo.pdf.

3. Министерство экономического развития Мурманской области. Официальный сайт. - [Электронный ресурс]. - Режим доступа. http://minec.gov-murman.ru.

(c) Чепурина Елена Олеговна (sekretarsha71@rambler.ru), Щебарова Наталья Николаевна (censey@mail.ru).

Журнал «Современная наука: актуальные проблемы теории и практики»

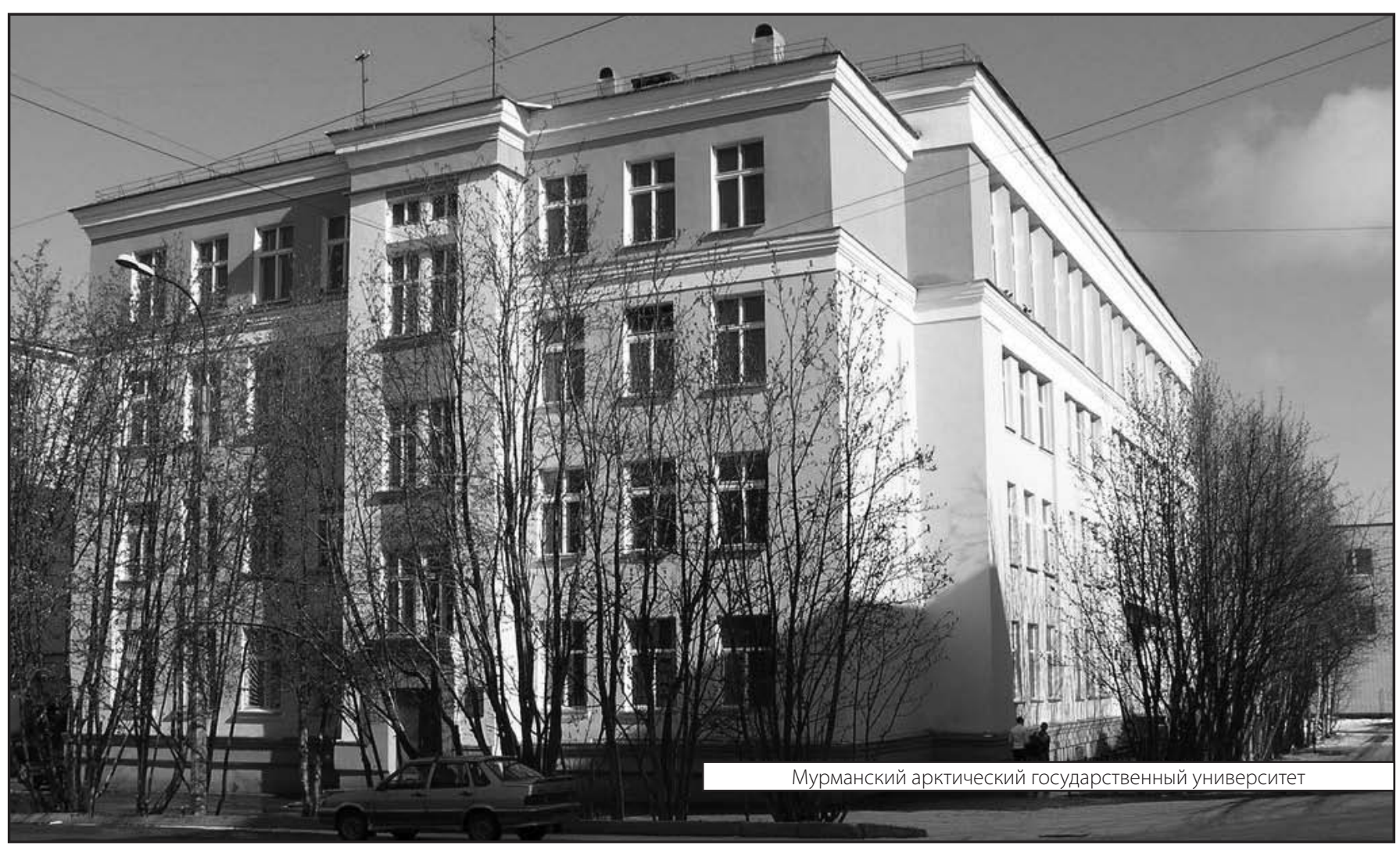

